\title{
Determination of the Heating Ability of Coal and Corn Cob Briquettes.
}

\author{
Ikelle Issie Ikelle and Ogah Sule Philip Ivoms \\ Department Of Industrial Chemistry, Ebonyi State University Abakaliki, Pmb 053, Nigeria, West-Africa.
}

\begin{abstract}
In this work briquettes of coal and corn cob were produced. The different briquette samples produced were made by blending various compositions of coal and corn cob in the following ratios of 100:0, 80:20, 60:40, 40:60, 20:80 and 0:100 using bitumen as a binder and calcium hydroxide as the desulphurizing agent. The briquettes were produced mechanically using a manual briquetting machine with pressure maintained at 5MPa. The results of the proximate analysis showed that the different compositions of the briquettes had reasonable calorific value but that $60 \%$ coal: $40 \%$ corn cob briquettes with following values for ash content $20.17 \%$, fixed carbon $44.83 \%$, moisture content $2.50 \%$, density $0.414 \mathrm{~g} / \mathrm{cm}^{3}$, volatile matter 32.50 $\%$, porosity index $48.12 \%$, calorific value $124.45 \mathrm{KJ} / \mathrm{kg}$, water boiling test $2.10 \mathrm{mins}$, ignition time $29.56 \mathrm{secs}$, burning time 19.76 mins and sulphur content $7.56 \%$ exhibited optimum combustible quality when compared with other compositions of briquettes produced.
\end{abstract}

Key words: briquette, biomass, coal, corn cob.

\section{Introduction}

A briquette is a block of compressed coal, biomass or charcoal dust that is used as fuel (Grainger et al., 1981). In the production of briquettes, the materials can be compressed without addition of adhesive, while in others adhesive materials called binders are added to assist in holding the particles of the material together depending on the type of raw material used for the production (Mohammed, 2005).

In an attempt to produce a better and more efficient briquette to reduce gases that contributes to green house effect, briquetting process has focused more on the production of smokeless solid fuels from coal and agricultural waste. The use of organic briquettes (biomass briquettes) started more recently compared to coal briquettes which are dated back to eighteenth century (Choudburl, 1983). The following are common types of briquettes in use, coal, peat, charcoal, and biomass briquettes. Corn cobs can be used for producing heat, power, gas/liquid fuels, and a wide variety of chemical products such as furfural, xylitol and activated carbon (Jiang and Morey, 1992).Recently, researches showed that blending of coal and biomass will give rise to a briquette with better combustion properties and environmentally friendly. Bio-coal briquettes are prepared by blending coal, biomass, binders and sulphur fixation agent. In the process, calcium hydroxide $\mathrm{Ca}(\mathrm{OH})_{2}$ acts as sulphur fixation agent. The de-sulphurizing agent in the briquette reacts with the sulphur present in the coal and converts about $60-80 \%$ of it into the ash, while lime $(\mathrm{CaO})$ as a de-sulphurizing agent captures up to $90-95 \%$ of the total sulphur in the coal leaving only $5-10 \%$ emitted as sulphur oxide which is more or less not harmful to the environment (Lu et al., 2000).

\section{Characteristics Of The Briquettes}

The main purpose of briquetting material is to reduce the volume and thereby increasing the energy density. When densification takes place, there are two quality aspects that need to be considered, firstly, the briquette has to remain in solid form until it has served its purpose (handling characteristics). Secondly, the briquette has to perform well as a fuel (fuel characteristics).

The energy characteristics are other important issues when describing and comparing briquettes with other fuels. The energy characteristics describe how the briquette act and what it produces when burned. The calorific value of briquettes is an important measure of the amount of energy released from every briquette when burned. Briquettes are normally priced by weight, but still, the calorific value is the most important factor in determining the competitiveness of the fuel. The calorific value varies with ash content and moisture content. Different ash and moisture contents in briquettes result in different calorific values. Normally, the ash content of wood briquettes is about $0.7 \%$. The resulting calorific value is $17-18 \mathrm{KJ} / \mathrm{kg}$ as the normal moisture content in Swedish production is about $10 \%$ (Eriksson et al., 1990). 


\section{Materials And Methods}

Materials

Pulverised coal, corn cob, calcium sulphate, calcium hydroxide, electronic weighing machine, manual briquetting machine, electric milling machine, stop watch, muffle furnance, oxygen bomb calorimeter machine model-OSK 100A.

\section{Methods}

\section{The collection of samples}

The coal was collected from Onyeama mine and identified at Nigeria coal corporation Enugu, Nigeria. The corn cob was collected from waste dump site at Kpirikpiri market in Abakaliki of Ebonyi state, Nigeria.

\section{Preparation of the briquetting sample}

The coal sample was sun dried for five days to reduce its moisture content, broken into smaller sizes using a hammer. The coal samples were then ground in an electric milling machine to pass through $1 \mathrm{~mm}$ sieve and stored.The corn cob was collected, sun dried for five days to reduce the moisture content, ground and sieved through $1 \mathrm{~mm}$ sieve and stored.

\section{Production of the briquette samples}

The briquettes were produced using a manual hydraulic briquetting machine with three cylindrical mould of $1.5 \mathrm{~kg}$. Briquettes of coal and corn cob of different compositions were produced with a specific amount of $\mathrm{Ca}(\mathrm{OH})_{2}$ added based on the mass of coal was used as the desulfurizing agent and a certain amount of calcium sulphate based on the entire mass of the mixture was used as the briquette binder. During the production, specific quantity of water was added to the mixture to attain homogenity. The pressure was maintained at $5 \mathrm{MPa}$ throughout the production time. After the production of these briquettes, they were sun dried for 6 days before analysis.

\section{Proximate analysis of the briquettes}

Calorific value: The calorific value was determined using Oxygen Bomb Calorimeter of model-OSK 100A. Moisture content, ash content, volatile matter, fixed carbon, density, sulphur content in line with the ASTM D3173 specification were also carried out on the briquettes. The calorific value $(\mathrm{KJ} / \mathrm{kg})$ of the samples under test is calculated from the temperature rise of the VI in the calorimeter vessel and the mean effective heat capacity of the system. (Sumner et al., 1983)

$($ Ee + W1) TR-C)/S x 4.1868

Where the water equivalent of the calorimeter $(581 \mathrm{~g}), \mathrm{W}_{1}=$ quantity of water in the vessel, $\mathrm{TR}=$ Temperature rise ${ }^{\circ} \mathrm{C}, \mathrm{C}=$ correction factor from ignition $154 \mathrm{Cal}, \mathrm{S}=$ weight of sample in grams $(\mathrm{g})$.

Moisture content: A portion $(2 \mathrm{~g})$ each of the samples was weighed out in a wash glass. The samples were placed in an oven for 2 hours at $105^{\circ} \mathrm{C}$. The moisture content was determined using:

$\mathrm{MC}=\underline{\mathrm{W}}_{1}-\mathrm{W}_{2} \times 100$

$$
\mathrm{W}_{1}
$$

$\mathrm{W}_{1}=$ Initial weight

$\mathrm{W}_{2}=$ weight after drying.

Ash content: A Portion ( $2 \mathrm{~g}$ ) were placed in a preweighed porcelain crucible and transferred into a preheated muffle furnace set at a temperature of $600^{\circ} \mathrm{c}$ for 1 hour after which the crucible and its contents were transferred to a desiccator and allowed to cool. The crucible and its content were reweighed and the new weight noted. The percentage ash content was calculated thus:

$\operatorname{AC}(\%)=\left(\mathrm{W}_{2} / \mathrm{W}_{1}\right) \times 100$.

$\mathrm{W}_{2}=$ weight of ash after cooling.

$\mathrm{W}_{1}=$ Original weight of dry sample.

$\mathrm{AC}=$ Ash content. (ASTM 1992)

Volatile matter: A portion $(2 \mathrm{~g})$ of the sample was heated to about $300^{\circ} \mathrm{C}$ for 10 minutes in a partially closed crucible in a muffle furnace. The crucible and its content were retrieved and cooled in a desiccator. The difference in weight was recorded and the volatile matter was calculated thus:

$\mathrm{VM}=\left(\underline{\mathrm{W}_{1}}-\underline{\mathrm{W}_{2}}\right) \times 100$

$\mathrm{W}_{1}$

$\mathrm{Vm}=$ Volatile matter

$\mathrm{W}_{1}=$ Original weight of the sample. 
$\mathrm{W}_{2}=$ Weight of sample after cooling.

Fixed carbon: The fixed carbon was determined using the formula

$\mathrm{FC}(\%)=100-(\% \mathrm{VM}+\% \mathrm{AC}+\% \mathrm{MC})$

Where $\mathrm{VM}=$ Volatile matter

$\mathrm{AC}=$ Ash content

$\mathrm{MC}=$ Moisture content

Density: A calibrated graduated cylinder was used for the estimation of destiny. The cylinder was packed with the samples and compacted. The density was thus calculated thus:

Density $\left(\mathrm{g} / \mathrm{cm}^{3}\right)=\underline{\text { Mass }(\mathrm{g})}$

\section{Ignition time}

$$
\text { Volume }\left(\mathrm{cm}^{3}\right)
$$

The different samples were ignited at the edge of their bases with a burnsen burner. The time taken for each briquette to catch fire was recorded as the ignition time using a stopwatch.

\section{Burning time}

This is the time taken for each briquette sample to burn completely to ashes. Subtracting the time is turned to ashes completely from the ignition time gives the burning rate.

Burning rate $=$ Ashing time - Ignition time

\section{Water boiling test / burning efficiency}

This was carried out to compare the cooking efficiency of the briquettes. It measures the time taken for each set of briquettes to boil an equal volume of water under similar conditions.100g of each briquette sample was used to boil $250 \mathrm{ml}$ of water using small stainless cups and domestic briquette stove.

\section{Total Sulphur Content:}

The different samples of the briquettes was pulverized, $1 \mathrm{~g}$ of the finely powdered samples was mixed with $5 \mathrm{~g}$ of $\mathrm{Na}_{2} \mathrm{NO}_{3}$ and $0.2 \mathrm{~g}$ of $\mathrm{NaNO}_{3}$ in a crucible. The mixture was preheated at $400^{\circ} \mathrm{C}$ for 30 minutes in an electric muffle furnance and then fused at $950^{\circ} \mathrm{C}$, after fussion, the crucible was allowed to cool and was placed on its side in a $150 \mathrm{~cm}^{3}$ beaker. $\mathrm{HCl}$ was added to neutralize the $\mathrm{Na}_{2} \mathrm{CO}_{3}$ and boiled to precipitate the sulphate by treating with $\mathrm{BaCl}_{2}$. The precipitate treated with drops of $\mathrm{HF}$ and $\mathrm{H}_{2} \mathrm{SO}_{4}$, ignited and weighed again. Total sulphur is determined by the expression (Jackson, 1988).

$\%$ sulphur $=\underline{\mathrm{BaSO}}_{4}(\mathrm{~g}) \times 13.7 \times 100$

Weight of sample

Porosity Index: The porosity of the briquettes was determined based on the amount of water each sample was able to absorb. The porosity index was calculated as the ratio of the mass of water absorbed to the mass of the sample immersed in the water (Montgomery, 1978).

Porosity Index $=$ Mass of water absorbed $\times 100$

$$
\text { Mass of the sample }
$$

Table 1. Results of proximate analysis of the various briquette samples

\begin{tabular}{|l|l|l|l|}
\hline Briquette sample $(\%)$ & Moisture content $(\%)$ & Density $\left(\mathrm{g} / \mathrm{cm}^{3}\right)$ & Sulphur content $(\%)$ \\
\hline $100 \%$ CD & 2.15 & 0.714 & 8.22 \\
\hline $80 \%$ CD 20\%CCB & 1.20 & 0.453 & 8.79 \\
\hline $60 \%$ CD 40\%CCB & 1.50 & 0.414 & 7.56 \\
\hline $40 \%$ CD 60\%CCB & 2.50 & 0.242 & 6.39 \\
\hline $20 \%$ CD 80\%CCB & 3.38 & 0.222 & 5.89 \\
\hline $100 \%$ CCB & 4.06 & 0.154 & 3.01 \\
\hline
\end{tabular}

Key- $\mathrm{CD}=$ Coal dust, $\mathrm{CCB}=\mathrm{Corn} \mathrm{cob}$ 


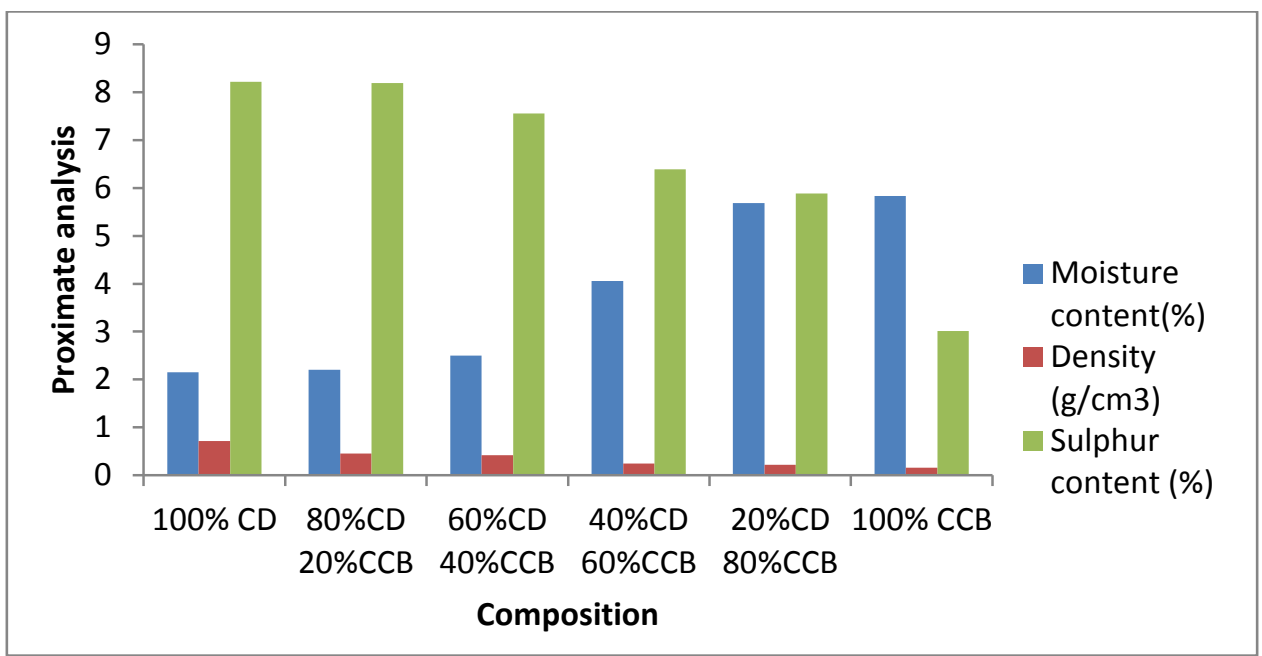

Fig 1. Plot of sulphur content, density and moisture content of the respective briquettes.

Table 2. Results of proximate analysis of the various briquette samples

\begin{tabular}{|l|l|l|l|l|}
\hline Briquette sample (\%) & Volatile matter(\%) & Ash content(\%) & Fixed carbon (\%) & $\begin{array}{l}\text { Porosity } \\
\text { index }(\%)\end{array}$ \\
\hline $100 \%$ CD & 11.76 & 21.05 & 65.04 & 22.02 \\
\hline $80 \%$ CD 20\%CCB & 26.48 & 37.69 & 50.69 & 39.68 \\
\hline $60 \%$ CD 40\%CCB & 32.50 & 32.30 & 44.83 & 48.12 \\
\hline $40 \%$ CD 60\%CCB & 36.12 & 27.45 & 40.40 & 53.66 \\
\hline $20 \%$ CD 80\%CCB & 41.41 & 23.00 & 34.09 & 69.87 \\
\hline $100 \%$ CCB & 45.77 & 18.88 & 30.71 & 78.69 \\
\hline
\end{tabular}

Key- $\mathrm{CD}=$ Coal dust, $\mathrm{CCB}=\mathrm{Corn}$ cob

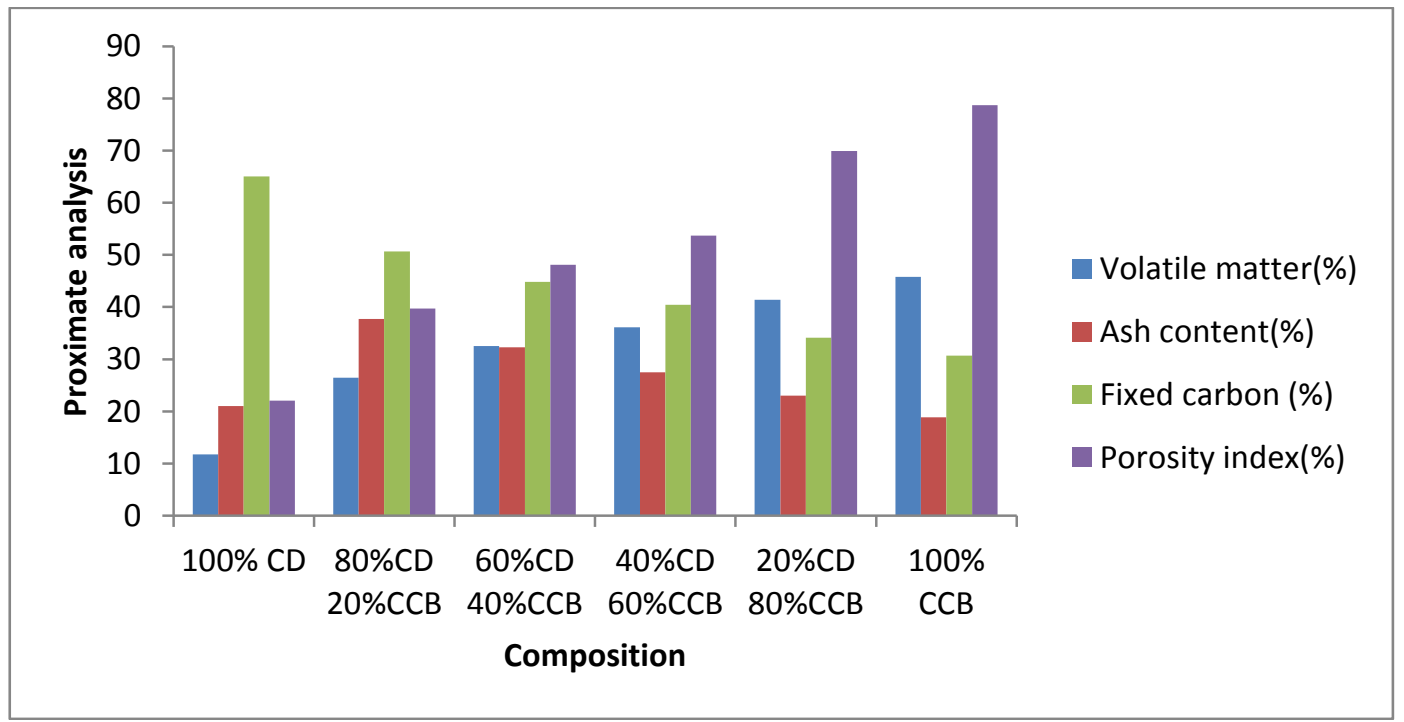

Fig 2. Plot of porosity index, fixed carbon, ash content and volatile matter of respective briquettes.

Table 3. The results of the calorific values of the samples

\begin{tabular}{|l|l|}
\hline Briquette sample & Calorific values KJ $/ \mathrm{kg}$ \\
\hline 100\%CD & 156.88 \\
\hline $80 \%$ CD20\%CCB & 148.36 \\
\hline $60 \%$ CD40\%CCB & 124.45 \\
\hline $40 \%$ CD60\%CCB & 114.56 \\
\hline $20 \%$ CD $80 \%$ CCB & 98.96 \\
\hline $100 \%$ CCB & 82.48 \\
\hline
\end{tabular}

Key $\mathrm{CD}=$ Coal dust, $\mathrm{CCB}=\mathrm{Corn}$ cob 


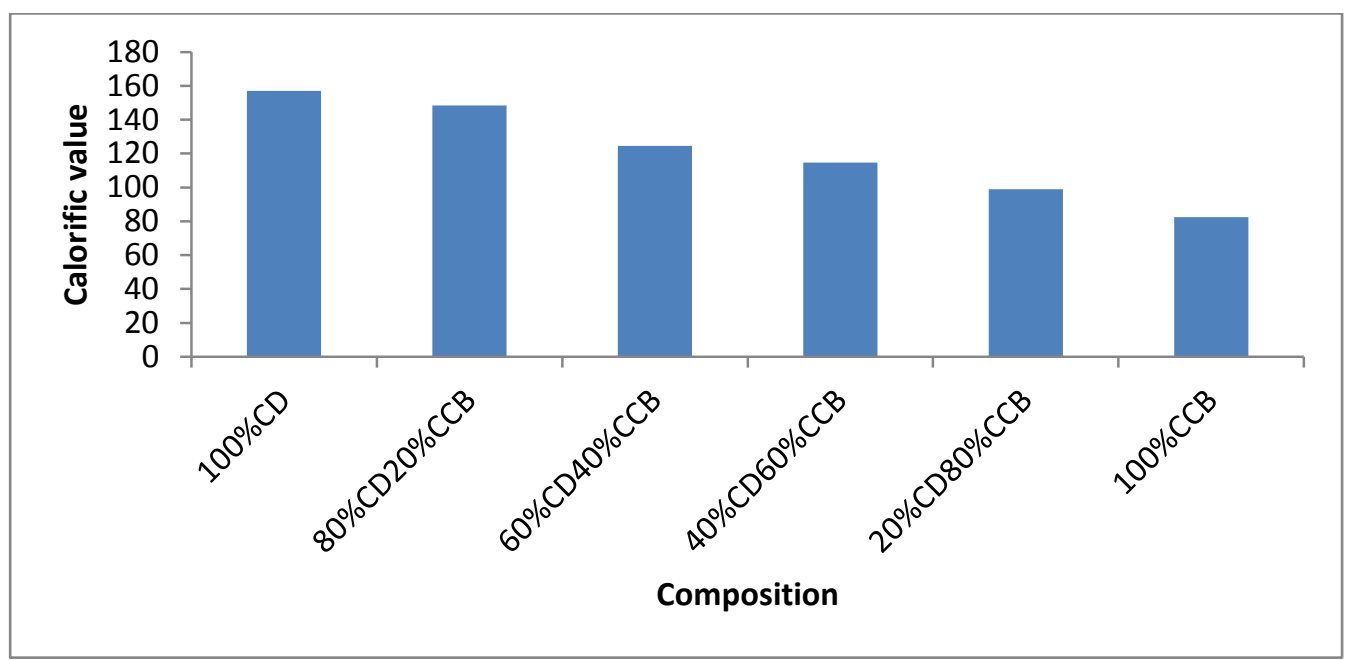

Fig. 3. Plot of the calorific values $(\mathrm{KJ} / \mathrm{kg})$ of the briquettes.

Table 4. The result of burning rate, burning time and ignition time

\begin{tabular}{|l|l|l|l|}
\hline Briquette samples & Water boiling test (min) & Burning time (min) & Ignition time (secs) \\
\hline $100 \%$ CD & 1.63 & 24.89 & 37.00 \\
\hline $80 \%$ CD20\%CCB & 1.64 & 23.28 & 56.14 \\
\hline $60 \%$ CD40\%CCB & 2.10 & 19.76 & 48.56 \\
\hline $40 \%$ CD60\%CCB & 2.62 & 18.56 & 43.10 \\
\hline $20 \%$ CD80\%CCB & 3.14 & 16.43 & 33.50 \\
\hline $100 \%$ CCB & 4.57 & 14.13 & 27.20 \\
\hline
\end{tabular}

Key- $\mathrm{CD}=$ Coal dust, $\mathrm{CCB}=\mathrm{Corn}$ cob

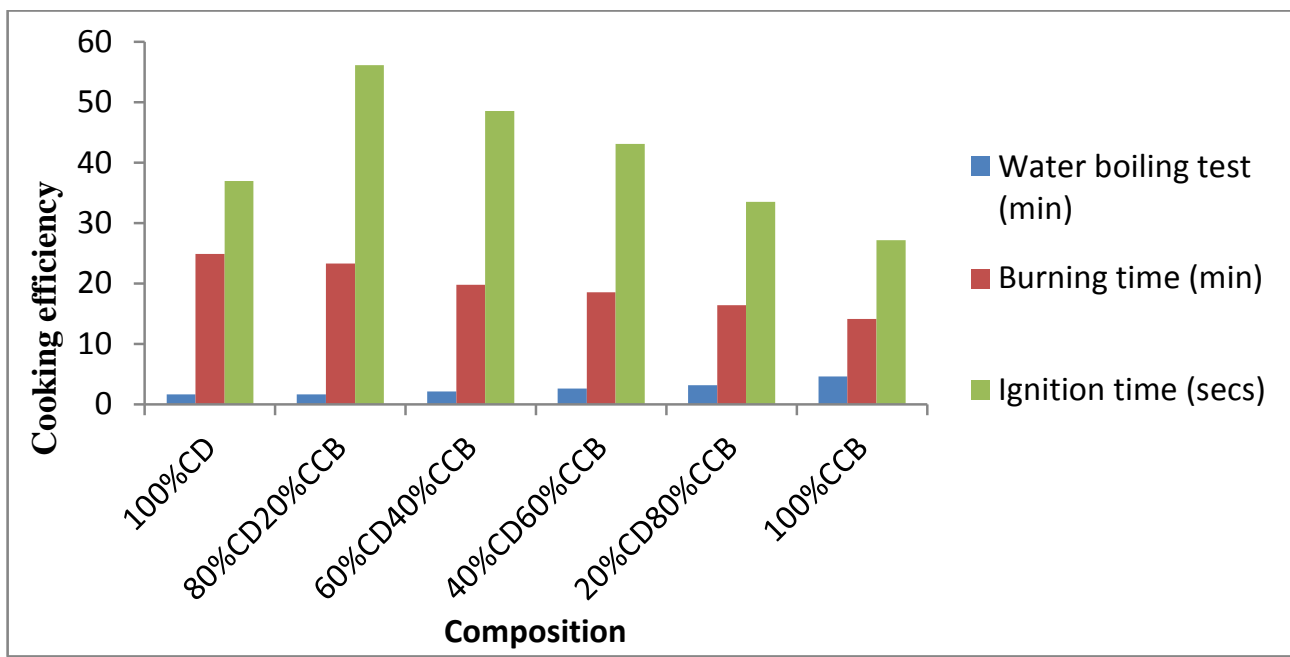

Fig. 4. Plot of cooking efficiency (water boiling test, burning rate and ignition time) of the respective briquettes produced.

\section{Discussions}

Corn cob particles are not strongly bound together their $100 \%$ briquettes had higher moisture content than other compositions produced. The moisture content is a measure of the amount of water in the fuel. In solid fuels, moisture can exist in two forms: as free water within the pores and interstices of the fuel, and as bound water which is part of the chemical structure of the material (Borman et al. 1998). Moisture content is a very important property and can greatly affect the burning characteristics of the briquettes (Yang et al. 2005). The briquettes of 100\% corn cob had the highest values of moisture content when compared to other compositions of briquettes. The briquetting of coal and corn cob reduces the moisture content. The density decreased with addition of corn cob to the coal and 100\% coal briquettes had the highest value. The $100 \%$ coal briquettes contained more sulphur but with the briquetting of coal and corn cob, introduction of the sulphur fixing agent $\mathrm{Ca}(\mathrm{OH})_{2}$ the sulphur content reduced. When cooking fuel contained free particles of combustible material it produces more volatile matter, $100 \%$ corn cob briquettes generated more volatile matter upon heating than 
$100 \%$ coal briquettes. To reduce the volatile matter and make the briquettes more suitable for combustion the composition of coal and corn cob were varied to yield briquettes with reduced volatile matter. Fixed carbon indicates the proportion of char that remained after the devolitization phase, production of briquettes from coal and corn cob by varying their compositions results in briquettes with reduced carbon content. Since coal is denser than corn cob, the briquettes produced with higher composition of coal had a higher density value than those briquettes of corn cob. The lower the porosity index of the briquettes the higher the density of the briquettes produced, the values showed that $100 \%$ coal briquette has a higher density than $100 \%$ corn cob. The calorific value (or heating value) is the standard measure of the energy content of a fuel. It is defined as the amount of heat evolved when a unit weight of fuel is completely burnt and the combustion products are cooled to $298 \mathrm{k}$. The ignition time of the briquettes improved with blending coal and corn cob. The briquettes produced are portable, safe to handle and with improved cooking efficiency due to the addition of the corn cob to the coal.

\section{Conclusion}

In conclusion, bio-mass briquettes have drawn worldwide interest as an energy source because it does not negatively affect the environment. These bio-coal briquettes are very efficient since the quality of solid fuel depends on the following factors; providing sufficient heat as at time necessary, igniting easily without danger, generating less smoke and gases that are harmful to environment, generating less ash, as these constitute nuisance during cooking. The briquette sample $60 \%$ coal: $40 \%$ rice husk yielded optimum combustible values when compared with the other blends of briquettes.

\section{References}

[1]. American Society for Testing and Materials, Annual Book of ASTM Standards (1992). Petroleum Products, Lubricants and Fossil Fuels, Section 5.50(12), 210-218.

[2]. Borman G.L. and Ragland K.W.(1998). Combustion Engineering, McGraw-Hill Science Publishers, pp 56-57.

[3]. Choudhurl, S. (1983). "Briquetting of Organic Residue" Proceedings from Bio-Energy Society Convention and Symposium, Delhi, 4(2) 22-28.

[4]. Eriksson S. M. P., (2006). The Briquetting of Agricultural Waste for Fuel, FAO Environment and Energy Paper 11,pp 78-80.

[5]. Grainger L. and Gibson, J. (1981). Coal Utilization Technology: Economics and Policy, Published by Graham and Trotman Limited, pp 3-7.

[6]. Jackson, M.L., (1988). Soil Chemical Analysis, Prentice Hall Inc. Englewood Cliffs, New Jersey, pp. 134-320.

[7]. Jiang, H. and Morey, R.V., (1992). Air-gasification of Corncobs at Fluidization, Biomass and Bioenergy 3: 87-92.

[8]. Lu, G. and Wang, Q.(2000). Experimental Study of Combustion and Pollution Control of Bio-briquette, Energy Fuels, 14: pp 11331138.

[9]. Mohammed, S.B., (2005). Bio-Coal Briquette, a Cleaner Affordable and Sustainable Fuel to Indonesia. www://unfccc.int/hcclean/ presentation/ bonn. Retrieved on 14th October 2012.

[10]. Montgomery, W.F., (1978). Standard Laboratory Test Methods for Coal and Coke in Analytical Methods for Coal and Coal Products, Academic Press, New York, pp. 194-224.

[11]. Sumner, H.R., Sumner, P.E., Harmnond, V.C., and Monroe, G.E. (1983). Indirect-fired Biomass Furnace Test and Bomb Calorimeter Determinations. Trans. ASAE 26(1) 238 - 241

[12]. Yang, Y.B., Ryu, C., Khor, A., Yates, N.E., Sharifi, V.N. and Swithenbank, J.(2005). "Effect of Fuel Properties on Biomass Combustion: Part ii, Modelling Approach-Identification of Controlling Factors", Fuel, 84, pp 2116-2130. 